\title{
Monitoring expression of yeast cell wall protein-encoding genes in response to high hydrostatic pressure
}

\author{
Tassia Nati ${ }^{*}$, Fernanda Bravim${ }^{1}$, Jimmy Soares ${ }^{1}$, Mainã Mantovanelli Mota ${ }^{1}$, James Riley Broach², \\ Antonio Alberto Ribeiro Fernandes ${ }^{1}$, Patricia Machado Bueno Fernandes ${ }^{1}$ \\ From 5th Congress of the Brazilian Biotechnology Society (SBBIOTEC) \\ Florianópolis, Brazil. 10-14 November 2013
}

\section{Background}

The cell wall $(\mathrm{CW})$ is one of the most important structures of the yeast cell, accounting for up to $30 \%$ of its dry weight. This organelle determines cellular morphology, affords mechanical protection and provides osmotic support. The yeast $\mathrm{CW}$ is a dynamic structure susceptible to many modifications, adjusting its composition and thickness to environmental changes. These responses usually involve changes in gene expression, increasing levels of proteins that have protective functions. High hydrostatic pressure (HHP) is a useful model of stress, which causes CW compression [1]. Exploring this process using the model organism Saccharomyces cerevisiae may allow us to understand the mechanisms of yeast stress tolerance in biotechnological processes and it may also helps in searching for effective antifungal drugs, since the $\mathrm{CW}$ is a desirable target of action.

\section{Methods}

In this work S. cerevisiae strain BT0510 was subjected to a non-lethal HHP of $50 \mathrm{MPa}$ for $30 \mathrm{~min}$, followed by recovery at atmospheric pressure for up to $15 \mathrm{~min}$. RNA samples were collected to perform a time series microarray expression analysis.

\section{Results and conclusions}

Through bioinformatics, changes in the expression pattern ( $\geq 2$ fold) of several CW organization and biogenesis genes were identified. HHP induced the expression of HSP12, which protein is present in CW and acts by increasing its flexibility [2], promoting survival under many stress

${ }^{1}$ Núcleo de Biotecnologia, Universidade Federal do Espírito Santo, Vitória, Espírito Santo, Brazil

Full list of author information is available at the end of the article conditions. The CW stress adaptive response is mainly mediated via Cell Wall Integrity (CWI) pathway, and its genes were affected by HHP. Rholp is the master regulator of CWI signaling, and is stimulated by Rom1p [3]. HHP induced the expression of ROM1. Mtl1p and Wsc3p are related in detecting and signaling $\mathrm{CW}$ status to Rholp; their genes were upregulated by HHP. Related to the same pathway, HHP activates $P K H 1$ and $P K H 2$, paralog genes of which proteins activate components of a signaling cascade required for CWI maintenance. The genes related to $\beta$-1,3-glucan, $\beta$-1,6-glucan and CW chitin biosynthesis were not strongly affected by HHP. Furthermore, MNN1, MNN9 and MNN10, correlated with protein mannosylation were downregulated by HHP. The products of these genes are subunits of mannose polymerase complexes, what suggest a possible change in the outer layer of the $\mathrm{CW}$. Moreover, HHP induced the coding genes of Pir3p Hsp150p, members of proteins with internal repeats family (PIR), correlated with CW reinforcement by interconnecting two or more $\beta$-1,3-glucan molecules providing defense against $\beta$-1,3-glucanases, common stress in the wild since these enzymes abound in plant tissues [4]. DSE2, DSE4, EGT2, CTS1, SCW11 and SUN4, related with CW degradation and separation of daughter cell from the mother cell, were downregulated by HHP, suggesting that pressure can affect cell division. Many genes involved in CW biosynthesis and organization had their expression changed after HHP treatment, evidencing the importance of the $\mathrm{CW}$ to ensure cell survival against this stress. Knowing the key cell-survival proteins is critical to improve biotechnological processes, and the results presented here may help in development of new drugs or in develop stress tolerant distillery yeast cells. 


\section{Acknowledgements}

CNPq, CAPES, MCTI, FINEP and FAPES.

\section{Authors' details}

${ }^{1}$ Núcleo de Biotecnologia, Universidade Federal do Espírito Santo, Vitória, Espírito Santo, Brazil. ${ }^{2}$ Penn State University College of Medicine, Hershey, PA 17033, USA.

Published: 1 October 2014

\section{References}

1. Bravim F, Freitas JM, Fernandes AAR, Fernandes PMB: High hydrostatic pressure and the cell membrane stress response of Saccharomyces cerevisiae. Ann NY Acad Sci 2010, 1189:127-132.

2. Karreman RJ, Dague E, Gaboriaud F, Quilès F, Duval JFL, Lindsey GG: The stress response protein $\mathrm{Hsp12p}$ increases the flexibility of the yeast Saccharomyces cerevisiae cell wall. Biochim Biophys Acta 2007, 1774:131-137.

3. Levin DE: Cell Wall Integrity Signaling in Saccharomyces cerevisiae. Microbiol Mol Biol Rev 2005, 69:262-291.

4. Klis FM, Boorsma A, De Groot PWJ: Cell wall construction in Saccharomyces cerevisiae. Yeast 2006, 23:185-202.

doi:10.1186/1753-6561-8-S4-P205

Cite this article as: Nati et al:: Monitoring expression of yeast cell wall protein-encoding genes in response to high hydrostatic pressure. BMC Proceedings 2014 8(Suppl 4):P205.

\section{Submit your next manuscript to BioMed Central} and take full advantage of:

- Convenient online submission

- Thorough peer review

- No space constraints or color figure charges

- Immediate publication on acceptance

- Inclusion in PubMed, CAS, Scopus and Google Scholar

- Research which is freely available for redistribution

Submit your manuscript at www.biomedcentral.com/submit 